This item was submitted to Loughborough's Research Repository by the author.

Items in Figshare are protected by copyright, with all rights reserved, unless otherwise indicated.

\title{
A stakeholder analysis of the automotive industry's use of compressed natural gas in Nigeria
}

\section{PLEASE CITE THE PUBLISHED VERSION}

http://dx.doi.org/10.1016/j.tranpol.2016.09.001

\section{PUBLISHER}

(C) Elsevier

VERSION

AM (Accepted Manuscript)

\section{PUBLISHER STATEMENT}

This work is made available according to the conditions of the Creative Commons Attribution-NonCommercialNoDerivatives 4.0 International (CC BY-NC-ND 4.0) licence. Full details of this licence are available at: https://creativecommons.org/licenses/by-nc-nd/4.0/

\section{LICENCE}

CC BY-NC-ND 4.0

\section{REPOSITORY RECORD}

Ogunlowo, Femi, Abigail Bristow, and M. Sohail. 2019. "A Stakeholder Analysis of the Automotive Industry's Use of Compressed Natural Gas in Nigeria”. figshare. https://hdl.handle.net/2134/22832. 


\section{A stakeholder analysis of the automotive industry's use of compressed natural gas in Nigeria}

Olufemi O.Ogunlowo ${ }^{1, \text { a }}$, Abigail L. Bristow ${ }^{1, \mathrm{~b}}$, M.Sohail ${ }^{1, \mathrm{c}}$

${ }^{1}$ School of Civil and Building Engineering, Loughborough University, Loughborough, Leicestershire, LE11 3TU

ao.ogunlowo@lboro.ac.uk, ba.l.bristow @ lboro.ac.uk, cm.sohail@ lboro.ac.uk

Corresponding author: Olufemi O.Ogunlowo

Phone numbers: +447587605879 and +234 8022234055 


\section{ABSTRACT}

Nigeria experiences a perennial shortage of transportation energy despite being the world's eighth largest producer of crude oil and the seventh largest proven reservoir of natural gas. Partly as a result, the Nigerian government proposed the use of compressed natural gas (CNG) as an automotive fuel in 1997 as part of the efforts to harness the country's natural gas resources and address transportation energy challenges. However, the rate of adoption has been very low with natural gas vehicles constituting $0.04 \%$ of the national vehicle fleet. This paper presents a stakeholder analysis derived from interviews with senior executives of the leading organisations involved in the energy and transportation sectors in Nigeria. Analysis revealed thirty-one barriers and twenty-six policy proposals that were categorised into eight and four themes respectively. While there is a rarity of agreement across all stakeholder groups, we observed consensus on the suggestion for the removal of the subsidy on petrol and the need for the establishment of a coordinating agency to drive the use of CNG. The paper offers specific recommendations for the reform of the energy and transportation sectors, the introduction of fiscal and operational incentives and the creation of public awareness.

KEYWORDS: Nigeria, Greenhouse Gas, Transportation, Compressed Natural Gas and Stakeholders Analysis

\section{Introduction}

Nigeria has four refineries with a combined installed crude oil distillation capacity that exceeds domestic demand. However, the refineries are dilapidated and - partly as a result - do not operate anywhere near capacity thus compels the importation of more than $80 \%$ of the refined petroleum products consumed

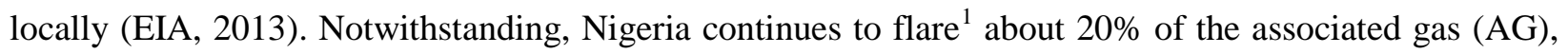
the raw natural gas (NG) encountered in the oil exploration and production process. According to the official data, 459 billion cubic meters of AG was flared between 1990 and 2010. This volume represents $51 \%$ of the of AG produced in the period and over 14.5 years worth of national gasoline consumption (see Ogunlowo, et al. 2016). The Nigerian government had proposed compressed natural gas (CNG) as a road

\footnotetext{
${ }^{1}$ Controlled burning of AG during discharge which emits gases that range between raw NG and ideal methane combustion emissions of water vapour and $\mathrm{CO}_{2}$ due to inefficiency (Buzcu-Guven, Harriss and Hertzmark, 2010)
} 
transportation fuel in 1997, in part, to harness the NG resources and address the twin challenges of gas flaring and transportation energy shortages. However, the rate of adoption has been slow with only less than 3,000 NGVs out of about 6 million vehicles in the national fleet and only eight operational CNG refuelling stations in nearly 20 years. This slow pace in the uptake of NGVs calls for a comprehensive review of the CNG implementation approach and an earlier comparative study which examined the NGV implementation approaches in seven countries with diverse experiences and identified the factors critical for success had recommended an analysis of stakeholders involved in the use of CNG in transportation in Nigeria with a view to aligning their interests and chart pathways for improvement (see Ogunlowo et al., 2015). Besides many authors have observed that stakeholder analyses are a key to solving problems especially when multiple parties are involved, and none has sole responsibility, and that public policies and institutions might fail in the absence of reasonable and satisfactory engagement of key stakeholders (see Bryson, 2004; Friedman, 2000; Eden and Ackennann, 1998; Huntington, 1996; Freeman, 1984). In specific context to alternative fuel vehicles (AFV), many authors have identified the need for stakeholder engagement and cooperation (see Yosie and Herbst, 1998; Chilton, 2000; Clift and Wright, 2000; Byrne and Polonsky, 2001; and Nijboer, 2010).

There are many definitions of stakeholder analysis, especially as the term has found application in many disciplines and, as observed by Gladwell (2000), has passed the 'tipping point' for everyday use. Nonetheless, the definitions are fundamentally the same but differ mainly on how inclusive they are. Essentially, stakeholder analysis is the process of identifying and understanding the perspectives of the entities that are involved in or may be affected by a project, programme, policy or any proposition. It is a systematic process of gathering, analysing and synthesising qualitative information to determine the concerns, interests and dispositions, which should be considered in the conceptualization, design and implementation of an idea, policy or programme. Stakeholder analysis involves the consideration and balancing of all the competing demands of each of the entities, especially the critical constituencies. It offers an avenue to identify the possibilities and mechanisms to influence other stakeholders, as well as 
the potential risks inherent in a proposition but does not guarantee that the interests of a particular stakeholder will override those of others (Fletcher et al., 2003).

Whereas literature review showed that stakeholder analysis is critical to the successful adoption of natural gas as an automotive fuel, no known study has analysed the stakeholders involved in the adoption of CNG as an automotive fuel in Nigeria. Thus, the aim of this study is to analyse the stakeholders involved in the use of CNG as a transportation fuel in Nigeria and identify the barriers and possible policy interventions that should be considered in the conceptualisation, design and implementation of any programme to improve the level of national use of CNG in transportation. This is premised on the sufficiency of scientific evidence on both the suitability and benefits of CNG as an alternative fuel (see Ogunlowo et. al, 2015). More so, there is evidence that widespread use of CNG in transportation will provide an opportunity to harness the NG resources, significantly reduce the energy-related GHG emissions from both transportation and flaring of AG and the associated economic losses, environmental degradation and the risk to public health (see IPCC TAR WG1, 2001; Igweonu and Mbabuike, 2011; and Nwaoha and Iyoke, 2013).

The work reported here is an exploratory study that establishes the views of key stakeholders at a senior level. It provides novel insights that might enable consensus building on potential policy interventions as well as lessons that could be useful in countries in a similar situation as Nigeria in their efforts to deploy AFV. The research scope was limited to policies and implementation approaches. The study exempted the technical evaluation of the automotive industry because vehicle supply is import-dependent. More than $85 \%$ of the nearly 150,000 vehicles imported annually are previously used (NAC, 2013).

The paper is structured as follows: Section 2 outlines the methodological approach; Section 3 discusses the results drawn from interviews with the stakeholder group and Section 4 draws out common themes. Section 5 presents the conclusions and policy implications. 


\section{Methods}

The aim of this study fits into the hermeneutic understanding category of research purpose and lends itself to the use of a qualitative enquiry with an interpretive standpoint (see Willis, 2007), which suits the application of descriptive category of conceptual frameworks (see Shields and Hassan, 2006). Accordingly, we employed the descriptive conceptual framework illustrated in Figure 1.

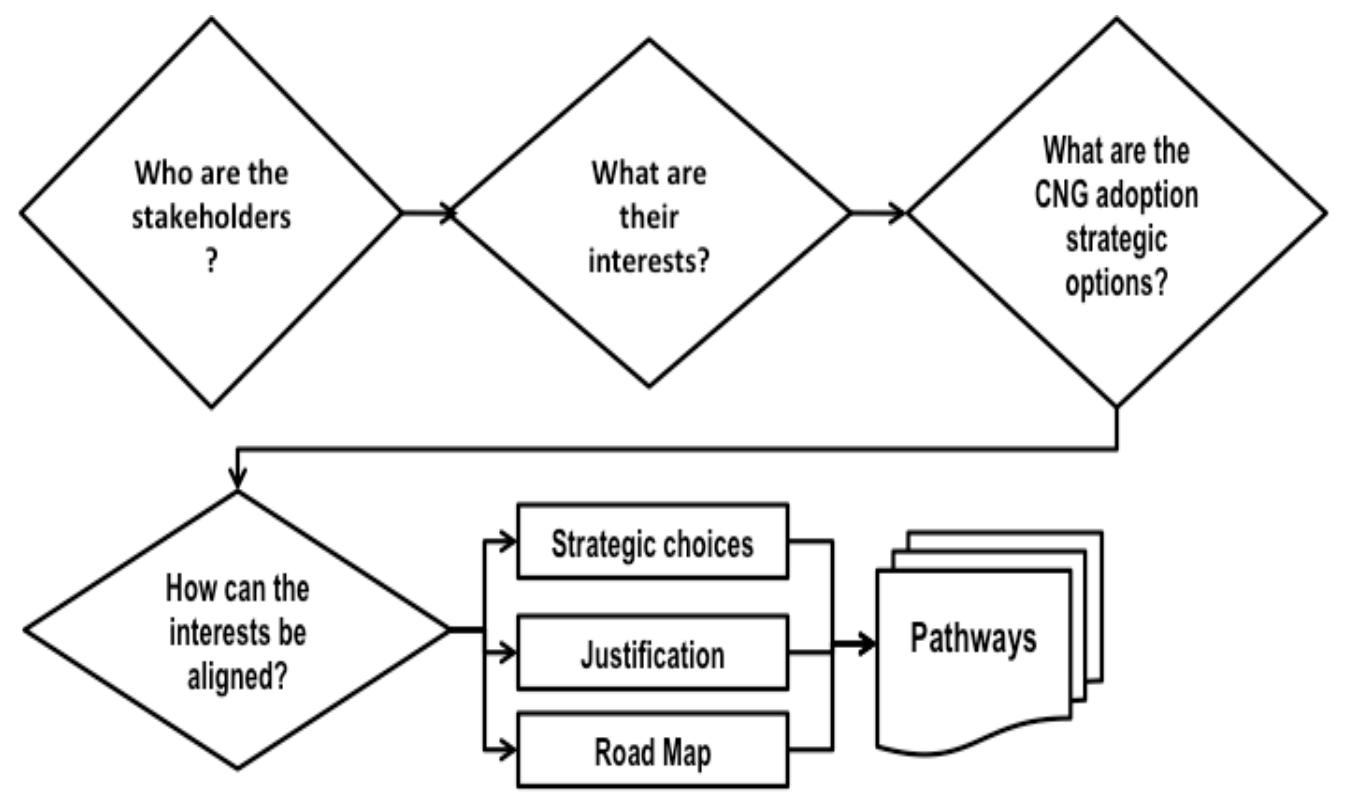

Figure 1: Conceptual Framework

\subsection{Identification of stakeholders}

To determine the stakeholders involved in the use of CNG as an automotive fuel, we used the taxonomies provided by PMI (2008) and Byrne and Polonsky (2001) as guides and applied a three-stage process involving stakeholder identification, grouping by market sector, and finally labelling of groups. Consequently, four stakeholder categories were identified comprising of the supply, demand, regulatory and advocacy groups.

The supply group consists of the three sectors of the oil and gas industry- upstream (prospecting, drilling and production), midstream (shipping and storing) and downstream (refining and distribution of products to consumers). The country is the majority shareholder in the upstream sector through the NNPC, which 
holds the equity under joint venture agreements ${ }^{2}(\mathrm{JV})$ or by engaging other parties as contractors in production sharing contracts ${ }^{3}$ (PSC) or service contracts ${ }^{4}$ (SC). Seven JVs, involving six international oil companies and a state-owned company, account for 97\% of total crude oil production while17 PSC and one SC share the remaining 3\% (NNPC, 2014). The midstream oil sector includes many operators but the Nigerian Gas Company (NGC), a subsidiary of the NNPC is the only gas transmission company. The downstream sector has five major and several small-to-midsized companies. One of the major companies operates a CNG mother station while others are not involved in CNG. The most visible operator is a midsized company, which operates in Benin, within the Niger Delta region. The demand group comprises of the organisations in the transportation sector including fleet managers, public transportation providers, vehicle retailers and auto assembly plants. There is no dominant mass transit or haulage company with significant national coverage or a dominant vehicle reseller. The regulatory group comprised of organisations with statutory mandates to set, implement and enforce rules or laws designed to control or govern the conduct and activities of the stakeholders in the demand and supply categories. There are three key demand side and five supply side regulatory agencies. The relevant bodies for the demand side are the Federal Ministry of Transportation, which amongst other functions is responsible for transport monitoring, evaluation, and research; the Standards Organisation of Nigeria, which establishes and monitors industrial quality standards; and the National Automotive Council, which facilitates the production of components and vehicles in Nigeria. Enforcement agencies include the Nigeria Customs Service, Nigeria Police and the Vehicle Inspectorate Office. The relevant regulatory agencies for the supply side are the Ministry of Petroleum Resources which initiates oil and gas policies and grants licenses, leases, and permits which are enforced through the Department of Petroleum Resources (DPR); the Petroleum Inspectorate, a department within the NNPC, responsible for the issuance of petroleum exploration and exploitation permits and licences; the Nigerian Content Monitoring Board responsible for supervising, coordinating, monitoring and managing the development of Nigerian content in accordance

\footnotetext{
${ }^{2}$ Parties share the cost and benefit according to proportionate ownership interest

${ }^{3}$ Allocates the right to crude oil to the contractor for cost, equity and tax and shares any balance thereof as profit

${ }^{4}$ Assigns no title to crude oil to the contractor
} 
with the Nigeria Content Act 2010; the Energy Commission of Nigeria which coordinates energy policy on consumption and production; and the Joint Authority which supervises the joint development of petroleum and other resources in accordance with the treaty between Nigeria and Sao Tome and Principe on the exclusive economic zones of both countries. Also, there are agencies at the Federal and state levels with the responsibility for the regulation of health, safety and the environment in the oil and gas industry. These include the DPR which has primary responsibility for the enforcement of safety and environmental standards, the Federal Ministry of Environment which administers environmental impact assessments of all projects, initiates environmental policies and implements the policies and applicable international standards through the National Environmental Standards and Regulation Enforcement Agency; the National Oil Spill Detection and Response Agency responsible for the detection and response to oil spillages; and the environmental protection agencies of the constituent states of the Federation. The advocacy category refers to those outside of the other three groups who speak or write in favour of, support or urge by argument or recommends publicly, transportation and/or energy policies in Nigeria.

Figure 2 illustrates the stakeholders and their groups.

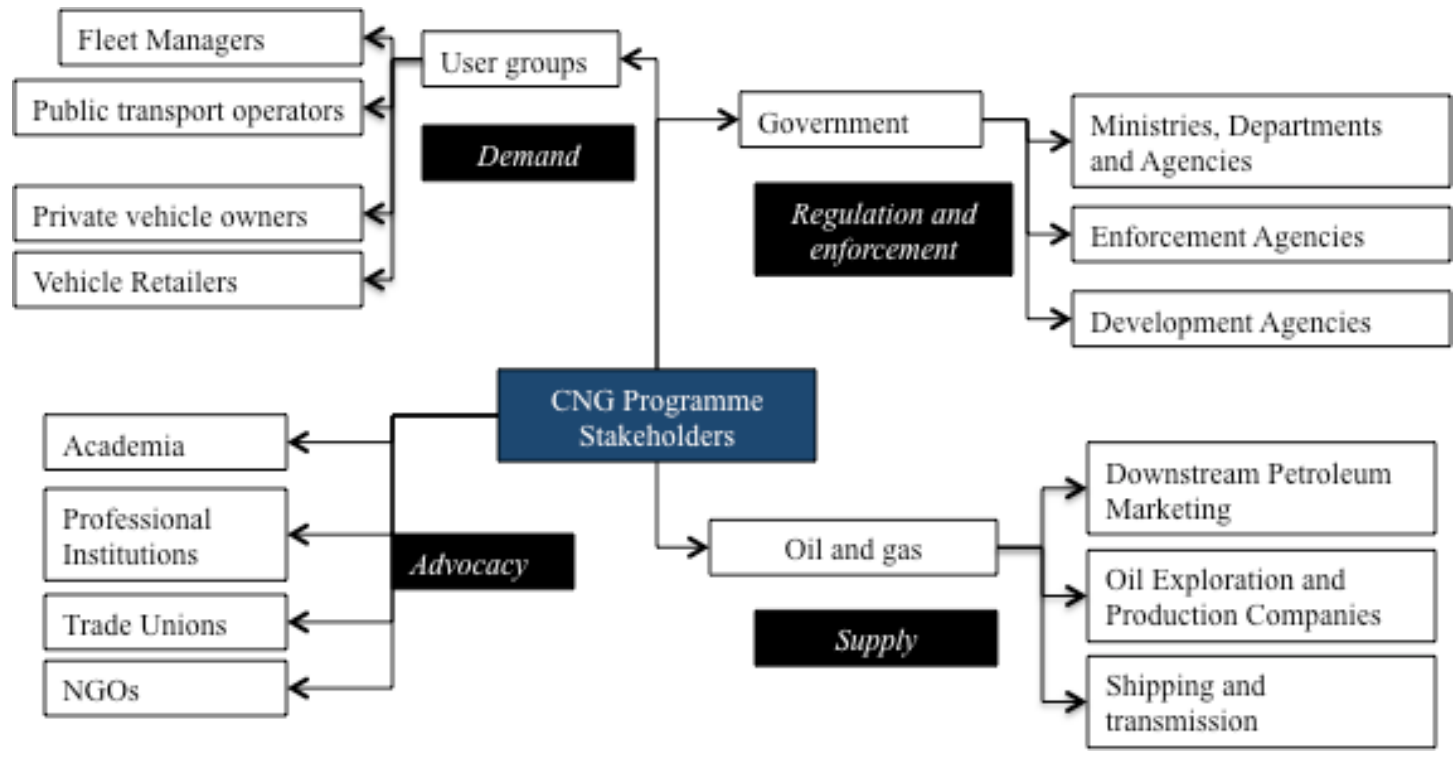

Figure 2: Stakeholder map 


\subsection{Research question}

The principal research question was: "what are the barriers to the use of natural gas as an automotive fuel in Nigeria and how can these be overcome?” The secondary questions are (1) Who are the critical stakeholders for NG utilisation as an automotive fuel? (2) What are the entrenched interests and concerns of stakeholders? (3) How can the stakeholders' interests and concerns be addressed? (4) What are the perceptions of stakeholders on the relative importance and severity of the identified barriers? (5) What steps should the country take to achieve widespread use of CNG as an automotive fuel?

\subsection{Data collection method}

The interview method was considered most suitable based on the research question. The method offers confidentiality, which was considered crucial as it was anticipated that data might include information on potentially sensitive business strategies. Kajornboon (2005) identified structured interviews, semistructured interviews, unstructured interviews and non-directive interview as the four principal types of interview. Among these, the person-to-person semi-structured form was chosen, as it is flexible and allows for probing for deeper meaning and understanding of relevant information that may not have been previously anticipated. The interview plan included the five secondary broad, open-ended questions.

\subsection{Selection of study participants}

The study employed corporate rather than personal participation considering the inherent difficulty associated with the independent identification and solicitation of individuals who are subject matter experts. A non-probability sampling method that involved homogeneous sampling of each market sector based on a variety of criteria listed in Table 1 was used. Twenty-six organisations were identified as critical stakeholders and invited to participate in the study. The participating organisations from both the upstream and downstream sectors of the supply group control over $70 \%$ of their respective markets while that of midstream is a monopoly. On the demand side, the fleet management and mass-transit companies have the largest fleet while the vehicle retailers are the leading brands with the most market share in the 
new vehicle segment. The regulatory agencies are the principal regulators of the petroleum industry and energy sector.

Table 1: Sectoral distribution of key stakeholders and evaluation criteria

\begin{tabular}{|c|c|c|c|c|}
\hline $\begin{array}{l}\text { Group } \\
\text { label }\end{array}$ & Market Sector & Homogeneous sampling criteria & $\begin{array}{l}\text { Number of } \\
\text { key } \\
\text { Stakeholders } \\
\text { who were } \\
\text { identified } \\
\text { and } \\
\text { participated }\end{array}$ & $\begin{array}{l}\text { Group } \\
\text { Total }\end{array}$ \\
\hline \multirow[t]{4}{*}{ Supply } & Upstream & \multirow{4}{*}{ Dominant market shares in own sector } & 2 & \multirow{4}{*}{11} \\
\hline & Downstream & & 6 & \\
\hline & Gas distribution & & 2 & \\
\hline & Gas transmission & & 1 & \\
\hline \multirow[t]{3}{*}{ Demand } & Fleet managers & \multirow{2}{*}{ Largest fleet size } & 2 & \multirow[t]{3}{*}{6} \\
\hline & Road transport & & 2 & \\
\hline & Vehicle retailers & Significant market share & 2 & \\
\hline Regulatory & $\begin{array}{l}\text { Government } \\
\text { agency }\end{array}$ & Relevance of mandate to the subject & 3 & 3 \\
\hline \multirow[t]{5}{*}{ Advocacy } & Trade & \multirow{2}{*}{$\begin{array}{l}\text { Relevance and influence on energy and land } \\
\text { transportation }\end{array}$} & 2 & \multirow{4}{*}{6} \\
\hline & $\begin{array}{l}\text { Professional } \\
\text { bodies }\end{array}$ & & 1 & \\
\hline & Academia & $\begin{array}{l}\text { Tertiary institutions offering core degrees or } \\
\text { postgraduate studies relating to energy, automotive } \\
\text { and road transport }\end{array}$ & 2 & \\
\hline & NGO & $\begin{array}{l}\text { Clear governance structure, focus on the environment, } \\
\text { transportation or energy }\end{array}$ & 1 & \\
\hline & Total & & 26 & \\
\hline
\end{tabular}

\subsection{Gaining access}

Gaining access was a formal process but, in some instances, it was facilitated by personal contact. In line with the findings of Chang and Chen (2009) that policy beliefs are positively related to officials' seniority, the letter of invitation requested that the organisations nominate senior management staff who were familiar with the developments on the adoption of CNG as an automotive fuel in Nigeria. Consequently, the participants were experienced senior executives comprising of principal officers of key government agencies, senior engineers, heads of logistics departments, heads of marketing departments, executive directors and chief executive officers in the transportation and energy sectors. Participants received an information sheet, which detailed the study purpose and other relevant information ahead of the interviews. 


\subsection{Fieldwork}

Interviews with a senior executive from each of the twenty-six main stakeholder organisations that participated in the study were conducted between August 2013 and August 2014 in the offices of the participants. Each interview lasted an average of 50 minutes, was tape recorded and subsequently transcribed.

\subsection{Analysis}

We followed the suggestion of Merriam (1998) and conducted the analysis of each interview before the subsequent interview. This enabled us to apply emerging insights in subsequent interviews using the principles of consistency (cross-checking the participant's testimony with other participants) and verifiability (cross-checking the participant's testimony with available public documents). Where necessary, we sought clarifications and conducted follow-up interviews via telephone and/or by email. We employed Hermeneutics ${ }^{5}$ principles for data analysis as it allows themes to emerge from the data, promotes a holistic understanding, shows the inter-relationships among themes, and retains a rich characteristic of individual ideas (Patterson and Williams, 2002).

Analysis followed the steps suggested by Patterson and Williams (2002, pp. 47-49) and was conducted at the individual level (idiographic) and across individuals (nomothetic) in two stages. In the first stage, the units of analysis were the participants (idiographic) and the stakeholder groups (nomothetic). In the second stage, each stakeholder group represented the idiographic analysis while the nomothetic analysis was across groups. We did not conduct a demographic analysis of the participants as the units and foci of analyses are the stakeholders and stakeholder groups. The results are presented in Section 3.

\footnotetext{
${ }^{5}$ The theory of interpretation and achieving an understanding of texts and utterances
} 


\section{Results}

\subsubsection{Barriers to the use of CNG as an automotive fuel in Nigeria}

This section presents the obstacles and policy recommendations stated expressly or inferred from the participants' narratives along the stakeholder groups. We have used unique alphanumeric codes to identify respondents and preserve anonymity and confidentiality.

\subsubsection{Supply group}

The views expressed by the respondents are categorised under seven themes, which are elaborated below.

Insufficient policy focus: The participants unanimously agreed that the focus of the government was the abatement of gas flaring and not gas utilisation. All the legislation between 1969 and 1990 only stipulated gas flare out dates and prescribed various penalties for default. None offered incentives for gas gathering. Consequently, oil and gas companies focused on gas reinjection rather than gas gathering or utilisation. This resulted in a significant increase in the volume and percentage of AG re-injected but slow adoption of gas consumption as a domestic fuel. Contrary to the official position of the NNPC, the interviewees unanimously disavowed the existence of a National Gas Master Plan and noted that the existing legislation is insufficient to stimulate growth in the domestic market and that current incentives are export-oriented. In addition, the participants observed that government had not shown enough seriousness in the move towards the use of natural gas noting that senior government officials have not been associated with the shift in contrast to the promotion of the use of ethanol between 1999 and 2003 when the then president was at the forefront. One respondent described the situation as "mere talks by middlelevel officials" (SSG02).

Unconducive energy market structure: Regulatory uncertainty, lack of transparency and limited access to information due to corruption and institutional inefficiency emerged as some of the impediments to the use of CNG. Interviewees argued that the market structure does not support long-term investment in NG citing the absence of market coordination, lack of policy on transportation use, old standards and operational guidelines in the downstream sector and arbitrariness in policy enforcement. In addition, 
participants identified petroleum products pricing framework as a major barrier noting that it is inconsistent and disadvantageous to domestic supply of natural gas as gasoline and kerosene are subject to price regulation and subsidy; the price of diesel is deregulated; and the price of NG is benchmarked to an absolute figure, which is denominated in US dollars and has historically been below market price. In the words of one respondent: "companies are encouraged to want to export their gas rather than put it in the domestic market because of the pricing mechanism which encourages more of export." (SSG02). . Literature sources suggest that nearly one-third of the national budget is applied to fuel subsidies (see Ogunmade and Ejiofor, 2014). The government attempted to remove the subsidy on gasoline and kerosene in 2012 but abandoned this policy in the light of public resistance.

There was apparent dichotomy in the views of the participants from the international oil companies (IOC) and those working with indigenous oil companies on the stalled Petroleum Industry Bill ${ }^{6}$ (PIB). Participants from the indigenous companies lauded the PIB and argued that it has a potential to promote transparency, accountability and growth. They blamed the impasse on the opposition of the IOCs to the proposed higher tax rate, a more transparent license allocation process and a compulsory financial provision for remediation of environmental damage and expressed concerns on the political will to pass the bill or enforce the law. Conversely, participants from IOCs argued that the PIB is detrimental to the industry and claimed that the provisions to increase the tax rate on gas projects to $80 \%$ from $30 \%$ would render all deep water and dry gas projects non-viable.

Poor transmission and distribution infrastructure: Nigeria has a gas transmission and distribution pipeline of about 2,756 $\mathrm{km}$ for its $923,768-\mathrm{km}^{2}$ area, and this is mostly concentrated in the southern part of the country. The majority of the participants considered the length of the pipeline paltry and blamed the small technological and industrial base for energy consumption in the country for the slow development of distribution pipelines. In the words of a respondent: "investment decisions are easier to make when

\footnotetext{
${ }^{6}$ The Petroleum Industry Bill (PIB) is a Bill for an Act To Provide for the Establishment of the Legal and Regulatory Framework, Institutions and Regulatory Authorities for the Nigerian Petroleum Industry; Establish Guidelines for the Operation of the Upstream and Downstream Sectors. The Bill was first introduced in 2008 and was revised and re-presented in 2012. It is yet to be passed into law.
} 
there are bulk buyers and retail becomes ancillary" (SSG21), arguing that the cost of "last-mile" pipeline is high because of the absence of main volume buyers with transmission lines from which the distribution lines could be connected. The dilapidation of the few government-owned corporations with dedicated supply pipelines - particularly the steel, aluminium and fertiliser companies - and the poor credibility of the erstwhile major bulk buyer, the government-owned Power Holding Corporation of Nigeria (PHCN), were identified as contributory factors to the lack of development of the distribution pipeline. Notwithstanding, the participants unanimously agreed that limited length and reach of the distribution pipeline is not necessarily a significant barrier to the automotive use of natural gas as trucks can service refuelling stations in the same way diesel and gasoline are transported nationwide. Albeit, they acknowledged that trucking is less efficient when compared to pipeline transmission but argued that CNG would remain competitive when trucked as all the alternatives are equally trucked.

Limited access to funding: It was a general view of the participants that Nigerian banks do not have the capacity to support major infrastructure development projects and that the risk of offshore borrowing is high because of the volatility of the Naira. They argued that indigenous operators resort to expensive short-term borrowing, which does not allow for long-term investment: a situation that they noted is a mismatch to the requirements of the industry, which is capital-intensive with long payback periods. The financing challenges make it difficult for indigenous companies to take a long-term view in their planning and investment decisions and the consequence is the inability to invest in CNG refuelling infrastructure. In the words of one of the participants: "not too many companies can afford it and not too many companies are willing to engage in such a long term contract” (SSG01).

Safety concerns: Two key issues emerged relating to safety, first, the general inexperience of the population with gas handling, particularly as the domestic use of gas is not widespread; and second, the safety of the converted vehicles as most vehicles on Nigerian roads are previously used and usually more than ten years old. One participant summed this up saying "there is a general apathy towards gas as biomass is the main source of domestic energy and majority of the people are not familiar with gas" (DSM02). 
Insecurity: Similarly, the participants consider the security of personnel and natural gas assets a major concern for the operators and constitute barrier to participation in the NG market. They cited militancy, vandalism and oil theft as the major security challenges noting that these have become ineluctable attributes of the region and that "this situation makes it difficult to invest in new ventures, especially those associated with major construction that transverses many communities, as would be required in the development of gas distribution pipeline” (GE01). Accordingly, "many international companies have reacted to the security challenges by designating Niger Delta as the dangerous and insecure place. With this perception, it will be difficult to attract global players to invest in new opportunities." (SSG19).

Difficult Niger Delta terrain: Interviewees from the upstream sector stated that Nigeria had been compelled to flare gas due to the difficult terrain of the Niger Delta and the limited number of appropriate reservoirs conducive for gas reinjection/storage. In the words of a respondent, "the volume of solution gas is between 6 and 8 percent of the total hydrocarbon reserves in energy terms and considering the mix and volume of associated gas and the difficult physical terrain of the Niger Delta, the cost of gas gathering becomes astronomical when compared to the economic benefit" (SSG19). The Niger Delta is the largest wetlands in Africa with about 36,000 $\mathrm{km}^{2}$ of marshland, creeks, tributaries and lagoons (Omotola, 2006). Figure 3 below illustrates all the views expressed by the group. 


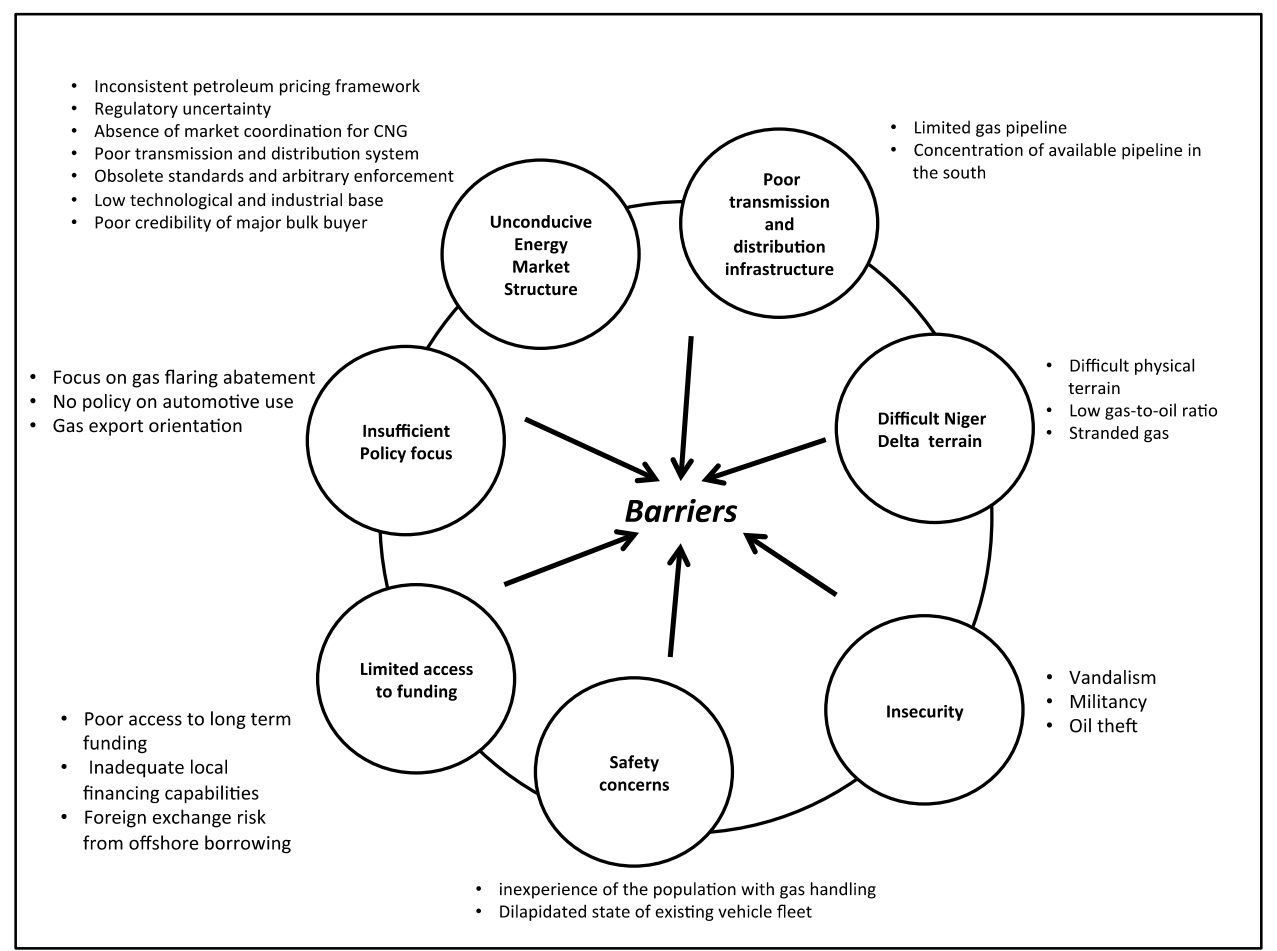

Figure 3: Perspectives of the supply group on potential barriers

\subsubsection{Demand group}

The barriers identified by the group are categorised into seven themes and presented below.

The Higher cost of NGV: Participants observed that the higher cost of NGV relative to conventional vehicles puts NGV in a disadvantaged position as purchase decisions are mostly based on price. They argued that this is worsened by the higher prices of vehicles in Nigeria compared to neighbouring countries due to higher import duties, inefficiencies and corruption in the clearing process. Also, they observed that recent increases in import duties, which are intended to encourage domestic production, resulted in higher prices. They argued that the new tariff might be detrimental to the use of NGV. Literature sources indicate that NGVs are about 10 to $15 \%$ higher than that of equivalent conventional vehicles, but this increased cost can be offset over the longer lifespan of the NGV, as it offers savings on fuel and maintenance costs (Pike Research, 2012; NGV Global, 2005). This differential price holds in Nigeria, as the local prices of natural gas vehicles are higher than those of equivalent conventional 
vehicles; possibly, because the country is completely import-dependent and hence local prices are a reflection of the cost in the country of origin.

Lack of integrated transport policy: The participants expressed uncertainty with respect to transportation policy, citing the failure of the National Transport Commission Bill 2009, the obsoleteness of the National Transport Policy 1993, the absence of standards for vehicle emissions, the focus of the fiscal regime for vehicle importation on age only, the absence of documented standards for vehicle retrofitting or NGVs, and the lack of procedures to check the conditions of imported previously used NGVs. Twenty years after, the views of the World Bank (1996), which remarked that the National Transport Policy 1993 had very few measurable policy goals or deadlines and that it has had little influence on the government's actions are still valid. More recently, Sumaila (2013) observed that all attempts at a national transport policy have remained as draft documents that were not adopted by the government due to lack of political will.

Poor transport infrastructure and safety considerations: Participants expressed the view that the state of Nigerian roads would be a risk factor for gas cylinders as the roads are poorly maintained, provide limited access and have poor complimentary services. They further observed that the vehicle fleet is old and dilapidated and may not be suitable for conversion. Indeed the National Automotive Council (2013) reports that over $85 \%$ of vehicles imported annually are previously used. An analysis of the age of vehicles imported in 2014 showed that $10 \%$ are less than three years old with about 63\% over 11 years.

Lack of standards: The use of CNG as an automotive fuel requires strict adherence to safety standards and the participants expressed doubts as to the capabilities of the existing enforcement agencies to undertake this stating that the Vehicle Inspection Office (VIO), Police Force and Customs Service lack the ability to enforce standards as officials can be easily compromised. When asked "What do you consider the major challenge in the adoption of CNG as automotive fuel in Nigeria?' The participants unanimously mentioned the lack of standards and the inability of existing institutions to enforce standards. 
Low public awareness: participants observed that there had been no public awareness initiatives to promote the automotive use of natural gas in contrast to the successful promotion of LPG as a cooking fuel. Figure 4 below illustrates the perspectives of the demand group on potential barriers.

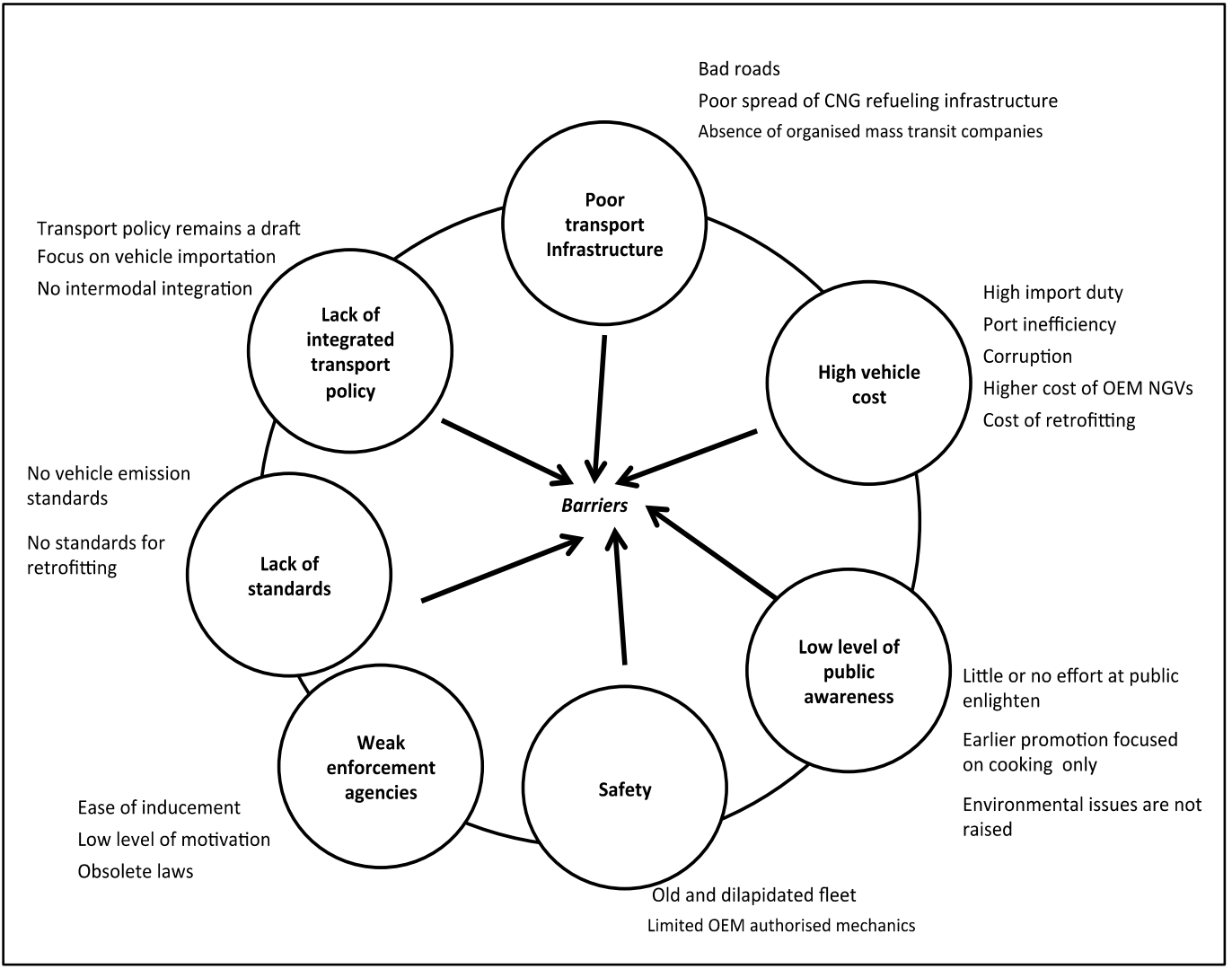

Figure 4: Perspectives of the demand group on potential barriers

\subsubsection{Regulatory group}

The major barriers identified are a lack of commitment by oil and gas companies, lack of distribution infrastructure, the non-inclusion of the transportation sector explicitly in the gas master plan as discussed below. As with other groups, the regulatory group also identified low level of public awareness and education as an impediment to the use of CNG as an automotive fuel in the country.

Lack of commitment by oil and gas companies: According to the participants, the government has made efforts to kick-start the CNG market, but the lack of progress is due to a low level of commitment by the operators. In the words of one respondent: " CNG franchises have been granted to different companies 
since 2008 for Lagos, Benin and Abuja, but only the Benin franchisee has commenced operation. Despite numerous assurances by the Lagos franchisee, there has been no progress made in the market. The case of Abuja is worse as every effort to locate the franchisee has proved abortive; indicating that the company has abandoned the franchise" (RSG02). Besides, the participants unanimously agreed that enough had not been done on raising public awareness on the benefits of CNG as an automotive fuel and as a result, the demand for NGVs is limited.

Lack of distribution infrastructure: The participants expressed the view that the lack of distribution infrastructure makes the supply of natural gas to industries difficult, and consequently affect the development of CNG stations along the pipeline route. They however noted the limited distribution pipelines in the Lagos-Ogun industrial axis and a number of private pipeline developments, such as the 128km South-South Gas Pipeline System which links the Calabar Cluster of Industries to the Nigerian Gas Company (NGC) grid, which they suggest will accelerate the development of the gas market and encourage the development of CNG stations along the pipeline route.

Non-inclusion of transport use of NG in the National Gas Master Plan: Although there are conflicting views on the existence of a National Gas Master Plan, the participants argued that the master plan exists as a collection of documents that include the National Domestic Gas Supply Policy, the National Domestic Gas Supply and Pricing Regulation, and the Gas Infrastructure Blueprint. They, however, considered non-inclusion of the transportation sector explicitly as a contributory factor to the slow progress in the adoption of CNG as an automotive fuel. Whereas the participants identified the delay in the passage of the PIB as a major challenge for the oil and gas industry, they agreed that Nigeria is not short of laws and regulations to reduce gas flaring but noted that the main challenge is enforcement, which they argued is due to circumstances beyond the control of the enforcement agencies. They suggested that it might be expedient for the government to "cherry pick" (RSG01) the provisions of the PIB, which are non-contentious and of significant impacts, such as the separation of the dual role of the NNPC as both operator and regulator for passage into law while conducting stakeholder engagement on other issues. Figure 5 illustrates the perspectives of the regulatory group. 


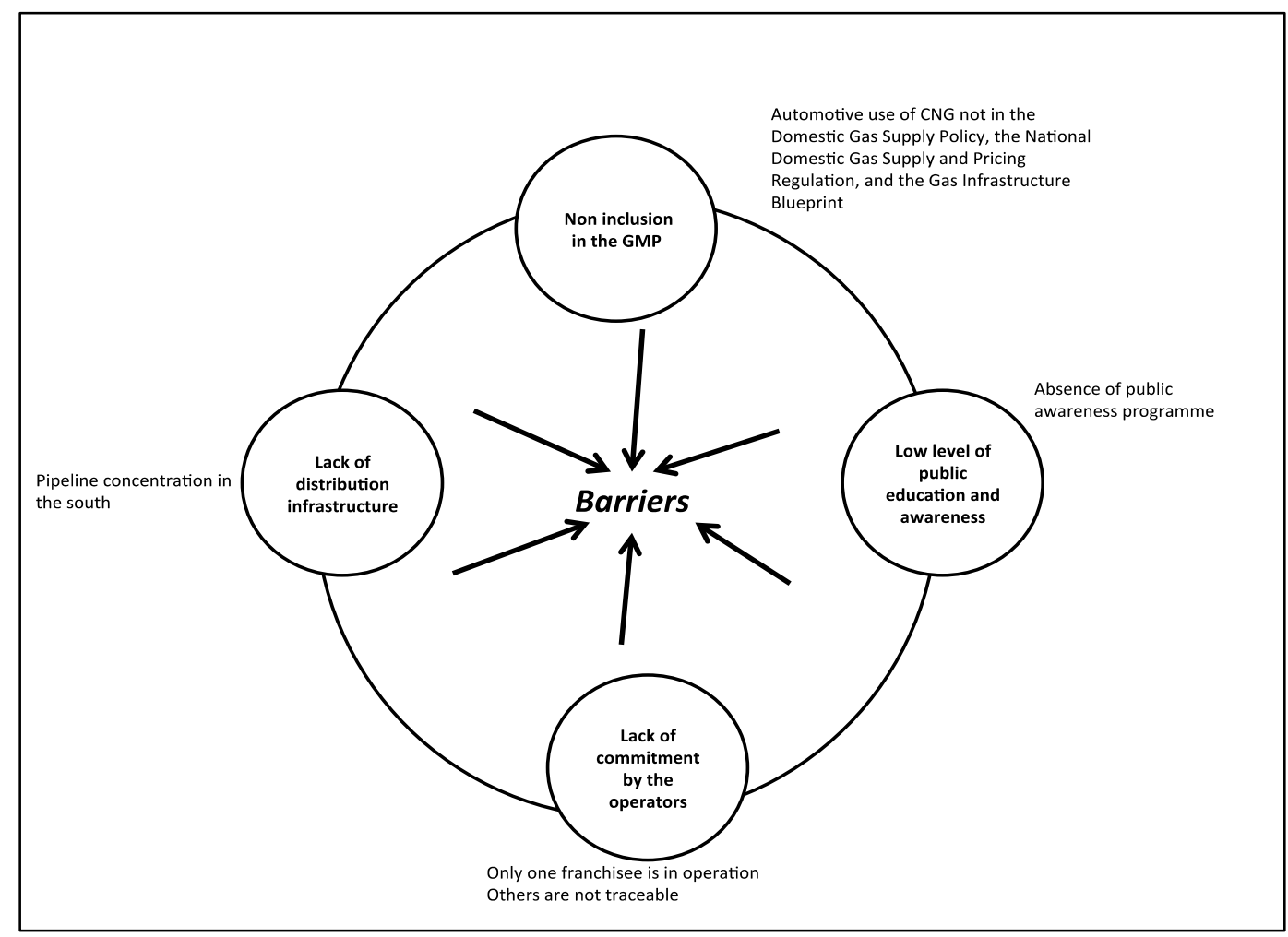

Figure 5: Barriers identified by the regulatory group

\subsubsection{Advocacy group}

The major concerns of this group are the non-separation of regulatory and operating functions of the NNPC; lack of transparency and accountability in oil asset administration and management; and safety.

Non-separation of the operating and regulatory functions of NNPC: According to the participants, separation of regulation and operation is necessary and fundamental. This is not the case with NNPC and according to participants; this may be responsible for the inefficiencies in the sector as the NNPC is the majority shareholder in petroleum operations. The respondents argued that the slow response of the NNPC to cash calls by the JV operators affected the growth and development of the sector including gas gathering initiatives. In the words of one respondent: "who do you hold accountable for flaring: the $60 \%$ single stakeholder or the minority holder?” (SAG01).

Lack of transparency and accountability: participants expressed the view that the absence of transparency and accountability constitute an obstacle in oil and gas industry. They argued that the administrative 
regime is fraught with abuse citing the fuel subsidy scam; the revelation that the NNPC did not have records of natural gas produced or sold by the NLNG for nearly 10 years; and the accusation by the then Central Bank Governor that the NNPC did not remit about USD 49.8 billion to the Federation Account. In the words of one respondent, "the reason why the business as usual mantra subsists is because its rent seeking -why invest in CNG when you can get free money?" (SAG03). The selection process for the CNG franchises was also called into question. The participants suggested that the abandonment of the programme by two franchisees was because they were handpicked and lacked the technical and financial capacity to undertake the exercise. A public hearing of the National Assembly in 2008 confirmed that the NNPC did not have records of natural gas sold by the NLNG a company in which it is the majority shareholder. However, the National Assembly concluded that the allegation of the Central Bank Governor was baseless but instructed the NNPC to refund the sum of USD 218 million to the Federation Account as being the cost of unaccounted oil in the period.

Safety concerns: The participants noted that the majority of auto mechanics in the country are illiterate, uncertified and dubious; a combination that portends a significant safety risk for retrofitting. In the words of one participant: "Despite the safety advantage of gas generally, I am concerned about mass adoption in Nigeria... Our mechanics are largely illiterates who learnt by apprenticeship, most of them do not understand the science behind what they do; I just think it's not that straightforward" (SAG03). Other safety concerns raised by the group are on the absence of any regulation or guidelines on retrofitting standards, an old and dilapidated vehicle fleet, a limited number of OEM authorised and certified mechanics and weak enforcement of standards. The participants expressed concern about the institutional capacity for standard enforcement noting that the MOT tests in many states of the federation are ineffective or non-existent. They further argued that the VIO is equally ineffective and only operates as an avenue to extort money from motorists. In the words of a participant: "the MOT was just copied from the UK without consideration for the implementation requirements. How can ill-equipped workshops undertake such an important assignment? It was ill-conceived and designed to fail. I think it died on arrival" (SAG01) 


\subsubsection{Proposed resolutions}

\subsubsection{Supply group}

Participants expressed interest in the restructuring of the energy market particularly the complete deregulation of the downstream sector through the removal of pump price subsidy on gasoline and kerosene and appropriate pricing of gas with the expectation that these measures would improve market efficiency and make gas more competitive. In addition, they proposed government intervention for the development of gas transmission pipelines similar to the 300 billion Naira ${ }^{7}$ (USD 2 billion), Power and Aviation Intervention Fund (PAIF) the Central Bank of Nigeria granted the power and aviation sectors in 2012. Other proposed interventions were the involvement of the NNPC in the operations of CNG refuelling stations in strategic locations similar to the experience of Argentina, fiscal incentives for the import of CNG refuelling equipment and components, leadership involvement in direction setting, and the creation of public awareness. The government was considered the most critical to market development particularly in formulating policy and stimulating infrastructure development. The specific expectations are for the government to develop a comprehensive gas policy that would include incentives for all market participants and to take an active lead role in gas infrastructure development. Industry and power plants are regarded as influential as they have the capacity for bulk buying which may provide cash flow for the further evolution of the sector particularly the last mile infrastructure. They are expected to be captive markets- due to the limited number of competitive suppliers- allowing for long-term financial projections (See Figure 6). The participants expressed optimism that the privatisation of PHCN in 2013 might improve the performance and cash flow of the successor companies and provide the impetus for further investments in downstream gas distribution to the benefit of the transport sector.

\footnotetext{
${ }^{7}$ Nigerian currency
} 


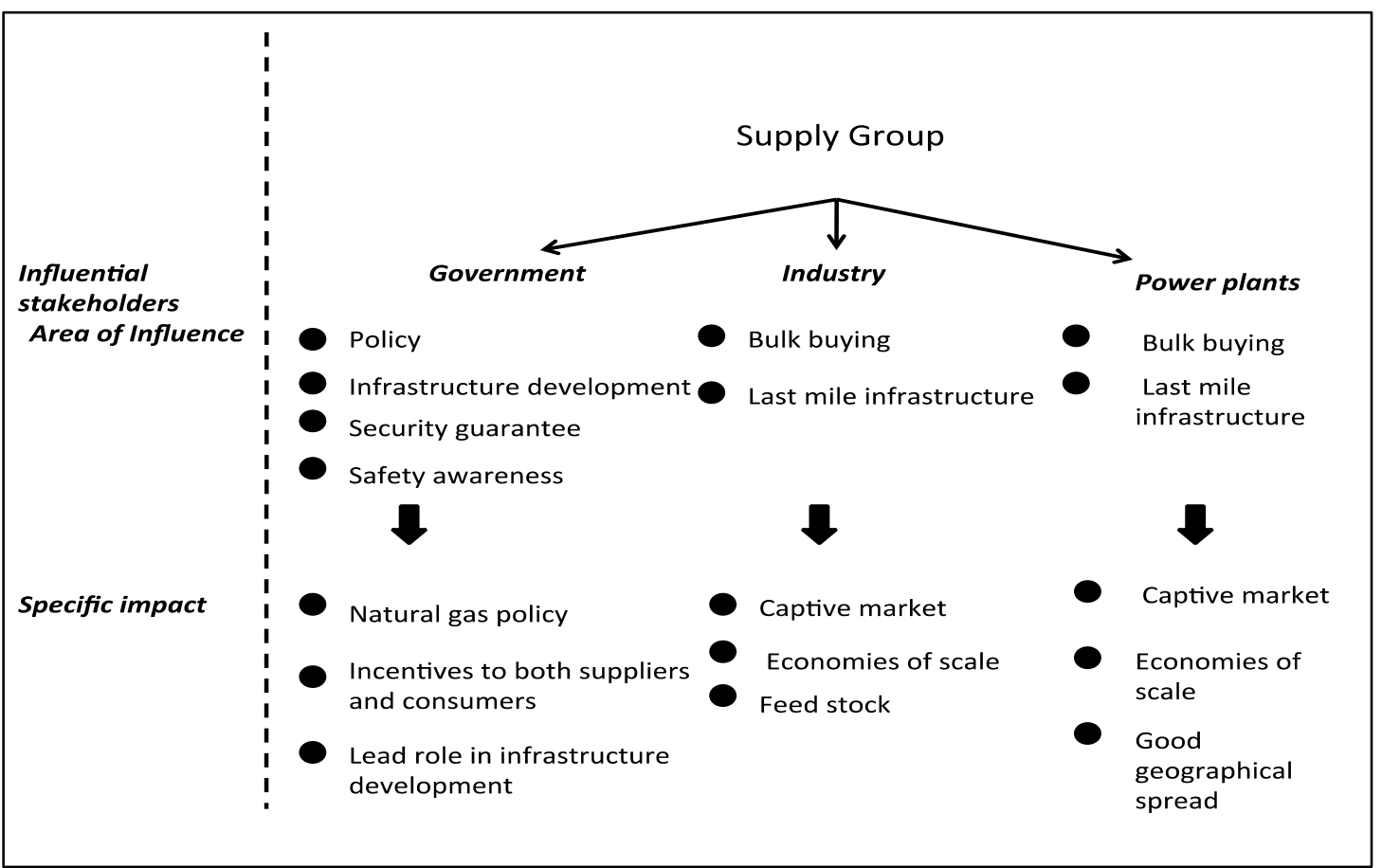

Figure 6: Perception of the supply group on stakeholders' influence

\subsubsection{Demand group}

The main interests expressed by the participants are the formulation of a comprehensive transportation policy which distinguishes between road development and a sustainable transport system, fiscal incentives, especially the waiver of duty for both NGVs and conversion kits for a specified period to encourage market penetration for NGVs, a public awareness campaign designed to highlight the current environmental challenges and espouse the benefits of CNG and statutory obligation for government fleets to include $10-20 \%$ NGVs. The participants considered the government as the most influential stakeholder noting that the government, as the major shareholder in oil and gas exploration, should be held accountable for the effective use of NG resources.

\subsubsection{Regulatory group}

The regulatory group advocated the promotion of Liquefied Petroleum Gas (LPG) as an alternative fuel alongside CNG. They cited the experience of Ghana and argued that LPG offers cost advantages in respect to the construction and operation of refuelling stations, conversion of vehicle, and adaptation of gas cylinders and is thus an easier proposition; arguments that are supported by PERC (2014) and 
Raslavicius (2014). However, CNG has safety advantages over LPG because LPG is stored in liquid form and is heavier than air and thus collects in low points and disperses more slowly than natural gas making it to be more susceptible to ignite or explode in the event of a leak (Energy Safety, 2012). Buzcu-Guven et al. (2010) observe that the extraction process might not be economical for associated gas that is produced in lower volumes and at lower pressure. Other suggestions offered by the group include the remodelling and upgrading of the Apapa port to accommodate larger vessels ${ }^{8}$ in order to facilitate product availability, the promotion of dual fuelled vehicles as well as a mandate for the government at all levels to convert $10-25 \%$ of their fleet to dual fuel, offer duty-free import of CNG refuelling station components and conversion kits, and 50-75\% subsidy on LPG conversion kits ${ }^{9}$ to spur market confidence and encourage uptake of NGVs. They further recommended the reduction of the applicable rates for the cost of perfecting title documents ${ }^{10}$ for land where refuelling stations are sited as well as a reduced rate for land use charge ${ }^{11}$ and tenement rates ${ }^{12}$. The participants considered the subsidy on petroleum products a sensitive matter and argued that until it is removed, the government should apply the same support to the CNG to correct the price gap distortion. They further argued that given that CNG is produced locally, and refined petroleum is imported, a CNG subsidy would reduce the overall burden on the government and strengthen the Naira, as it will reduce the foreign currency requirement for petroleum importation. Two of the three participants from the group proposed the expansion of subsidy to CNG as an equalisation mechanism if the government is unable to withdraw the subsidy on gasoline. In the words of a participant: "the market is distorted by petroleum subsidy, if it cannot be removed, then it should be applied in equal proportion for corrective measures. The benefit of CNG is hidden by the subsidy, and it has to be unlocked" (RSG02). They argued that while refined petroleum products are imported, CNG is locally available and thus has the potential to conserve the country's foreign reserve, even if subsidised.

\footnotetext{
${ }^{8}$ Maximum capacity of vessels that can berth in Apapa is 7,000 tons

${ }^{9}$ Average price for LPG conversion kit is USD 600 while that of CNG vary starting from about USD 3,000.

${ }^{10}$ The Land Use Act2004 vests all land, with the exception of land vested in the Federal Government or its agency, within the boundary of each state in the Governor of each state who is responsible for the management, control and allocation of land for residential, commercial and other purposes in urban areas. The law vests similar powers in the Local Government Chairman for rural areas. The allocation process or transfer of rights is at a cost.

${ }^{11}$ Property tax in Lagos state

${ }^{12} \mathrm{~A}$ tax charged on a property that is in full occupation by either a tenant or the owner of the property.
} 


\subsubsection{Advocacy group}

The advocacy group expressed interest in having an independent regulator for the industry and the formulation of a comprehensive safety assurance plan. They proposed the inclusion of a retrofitting programme in the curriculum of the Federal Technical Colleges and the establishment of model retrofitting workshops to be sponsored by the government, the gas industry and the auto industry. The group considered government as the most influential stakeholder but expressed the view that the petroleum industry operators are exploiting the inefficiencies in the system and thus considered the cooperation of the oil and gas operators particularly the IOCs as critical to the successful implementation of any strategic decision.

\section{Discussion}

This section draws out common themes and perspectives evident across the stakeholder groups. Analysis revealed thirty-one barriers across the stakeholder groups. Although some authors have suggested broad categories for the adoption of alternative fuels - for example, Browne et al. (2012) suggested four themes of financial, regulatory, legal and physical barriers - this study used eight themes expressly stated or inferred by the study participants to organise meaningfully, interpret and present the narratives. Table 2 elaborates the themes, the barriers under each theme, and the views of the interviewees from each stakeholder group where the "tick" indicates that at least a participant from the group expressed the view stated. As shown in the Table 2, complete agreement across all groups is rare, but is found largely around five relatively less controversial issues. The participants agreed that the pump price subsidy on gasoline distorts the energy market and reduces the attractiveness of CNG. They expressed the view that a price differential in favour of natural gas has been a major factor in the adoption of NGVs, a view that is supported by literature sources, such as Yeh (2007) and Collantes and Melaina (2011).

Table 2: Comparative analysis of identified barriers across stakeholder groups

\begin{tabular}{|c|c|c|}
\hline A. Insufficient focus and misplaced priority of policy on natural gas & S & \begin{tabular}{l|l|l}
$\mathbf{D}$ & $\mathbf{R}$ & $\mathbf{A}$ \\
\end{tabular} \\
\hline 1. Focus of government policy and legislation on abatement initiatives & 4 & \\
\hline 2. Absence of clear policy and regulation on automotive use of natural gas & 4 & 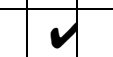 \\
\hline
\end{tabular}




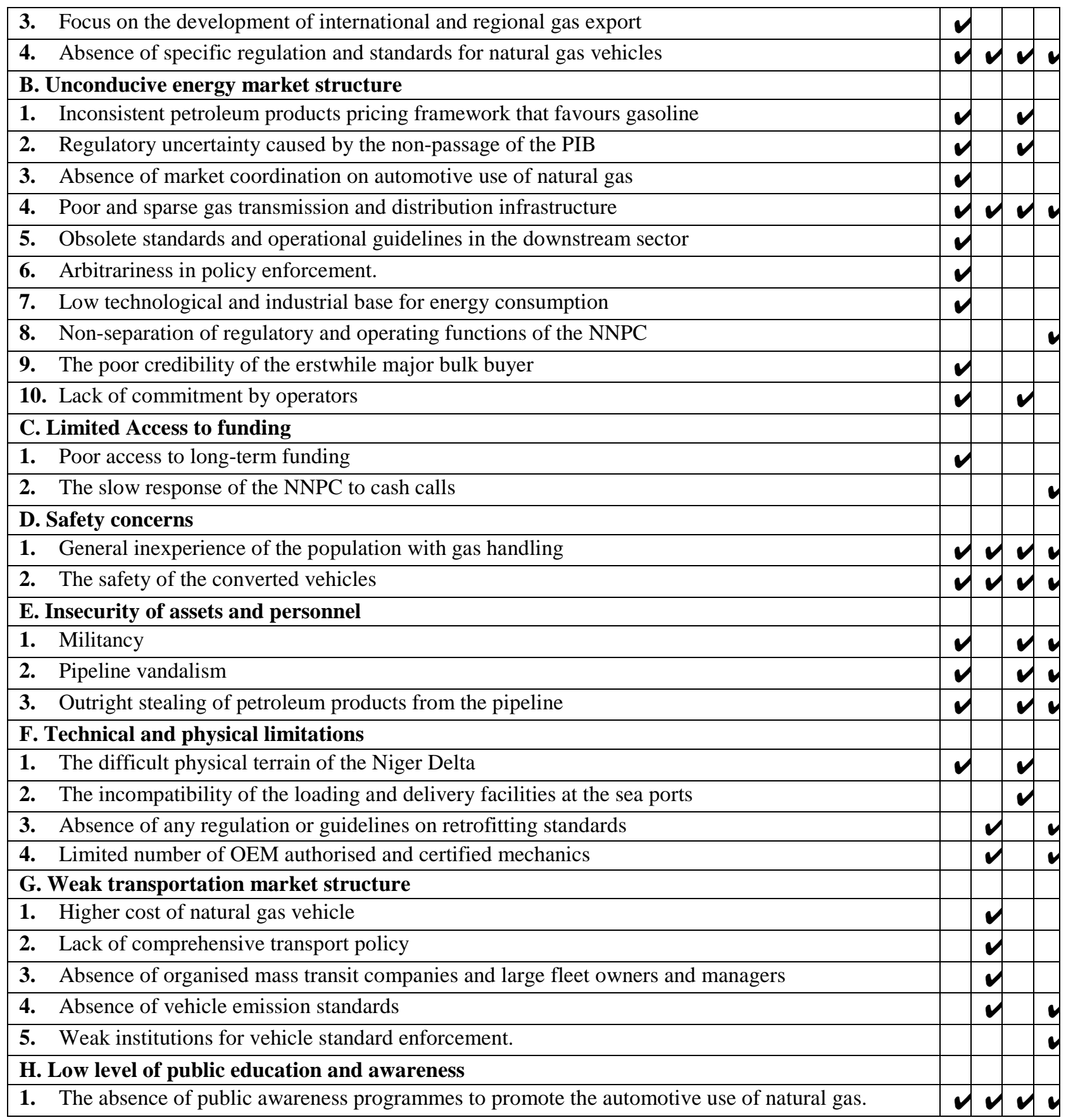
S= Supply
$\mathrm{D}=$ Demand
$\mathrm{R}=$ Regulatory $\mathrm{A}=\mathrm{Advocacy}$ 
Divergent views are found on the impact of the lack of distribution infrastructure and the existence of a National Gas Master Plan. Although all the groups agreed that the gas pipeline network is inadequate, participants from the Supply group argued that the lack of distribution infrastructure is not a major limiting factor, they argued that trucks could supply refuelling stations competitively, similar to the way conventional fuels are currently transported nationwide. However, participants from the Regulatory group argued otherwise and contended that the absence of pipelines has resulted in financial losses for industrial gas users. Similarly, participants from the Supply group questioned the existence of the National Gas Master Plan and suggested that if it exists, it has not had any impact on the industry. The Regulatory group argued that the master plan is a collection of existing documents. There was a clear dichotomy in the views of the participants from the Supply group along the downstream-upstream, IOC-indigenous company divide - particularly as it relates to the PIB and access to funding. While participants from indigenous companies favoured the passage of the PIB, those from the IOCs consider it inimical to further investments in the oil and gas industry. The most controversial provisions of the PIB are the envisaged discretionary powers for the Minister of Petroleum Resources, the establishment of a new Petroleum Host Communities Fund and the increase in taxation. Media reports indicate that IOCs have argued that Nigeria will have the harshest fiscal regime in the world if the PIB is passed into law (Okafor, 2013). Bowman (2012) reported that IOCs had withheld an estimated $\$ 40$ billion of investment in Nigeria pending the outcome of the passage of the PIB while Bala-Gbogbo and Ibukun (2013) reported that Nigeria risks losing \$185 billion within ten years if the PIB is passed in its current state.

A review of the Petroleum (Drilling and Production) Regulation 1969 and the Associated Gas Reinjection Act 1979 support the argument of the supply group that focus of government had been misplaced and centred on the abatement of gas flaring as seen in the provisions of the legislation. Albeit, the focus of government, changed to domestic utilisation in 2008, when the National Domestic Gas Supply Policy (the Policy) and the National Domestic Gas Supply and Pricing Regulation (the Regulation) were introduced. However, as observed by Ogunlowo, et al. (2015), the major shortcomings of the Policy and the Regulation are the non-inclusion of the transportation sector, low floor prices and 
non-completion of the legislative process. Though the Policy recognises the domestic commercial sector, the definition excludes transportation. Furthermore, the price of gas for the commercial sector is indexed to that of low pour fuel oil (LPFO) and not production and gas market dynamics. The provisions of both the Policy and the Regulation are yet to be backed by law, due to the non-passage of the PIB 2012. Hence, the Gas Regulatory Commission, which is a critical component of the Regulation, has yet to be established, and the domestic supply obligation is not enforceable.

As shown in Table 3, the analysis revealed 26 recommendations, which were categorised into four themes. All the policy proposals offered by the supply group are towards energy market reforms and the creation of public awareness through initiatives that could boost market and consumer confidence. As might be expected, the demand group suggested policies that centred on the transportation sector reforms while the recommendations of the regulatory and advocacy groups cut across the board. Surprisingly, 17 of the 26 policy proposals had support from only one stakeholder group while there was a consensus on only two recommendations; the proposals to remove the subsidy on the pump price of gasoline and establish a coordinating agency to drive CNG use. There is some convergence of opinion on the development of vehicle emissions standards and NGV safety assurance plan. As seen in India, a gradual, clearly signposted and explained removal of the subsidy might be expedient. Also, there are lessons from India, Argentina, Brazil and Iran concerning the establishment of a coordinating agency to drive CNG as these countries have applied the approach successfully. In India, GAIL (India) Limited was charged with the implementation of the CNG programme, in Argentina, Yacimientos Petrolífero Fiscales (YPF), a state-owned petroleum and NG exploration and production company, was charged with implementation while Gas del Estado, a state-owned NG transmission and distribution company was assigned the supervisory function. In Brazil, Inmetro was charged with the responsibility of establishing quality and safety regulations, Ibama was responsible for providing environmental related regulations, and Petrobras was responsible for the production and transportation of NG. The Iranian Fuel Conservation Organisation (IFCO) was established to oversee fuel consumption, undertake national conservation activities, and manage and promote the utilisation of CNG as a transport fuel. In Pakistan, the Ministry of Petroleum 
and Natural Resources provided policy initiatives and coordinated the implementation while the Oil and Gas Regulatory Authority and Hydrocarbon Development Institute of Pakistan regulated and conducted research and development respectively (see Ogunlowo et al., 2015; 2016).

A wide range of incentives was proposed for CNG refuelling infrastructure development, retrofitting kits and natural gas vehicle acquisition. The experience of Pakistan, which has the highest NGV penetration rate in the world, suggests that incentives to corporations to provide refuelling infrastructure have higher impact than consumer incentives. Hence, the proposals for a tax rebate on land used for CNG stations and import duty concession for retrofitting kits, CNG equipment and components may have a higher impact (ibid.).

Table 3: Comparative analysis of proposed policy interventions across stakeholder groups

\begin{tabular}{|c|c|c|c|c|}
\hline Proposed policy interventions & $\mathrm{S}$ & $\mathrm{D}$ & $\mathrm{R}$ & A \\
\hline \multicolumn{5}{|l|}{ Energy market reforms } \\
\hline 1. Remove pump price subsidy on petrol & $\boldsymbol{V}$ & $\boldsymbol{V}$ & $\boldsymbol{V}$ & $\boldsymbol{L}$ \\
\hline 2. Adopt market-based pricing for domestic supply of NG & $\boldsymbol{v}$ & & $\boldsymbol{v}$ & \\
\hline 3. Extend existing fuel subsidy to NG until it is removed from gasoline & & & $\boldsymbol{V}$ & \\
\hline 4. $\quad$ Pass PIB into law 'as-is.' & $\boldsymbol{V}$ & & & \\
\hline 5. Pass less controversial provisions of PIB in the first instance & $\boldsymbol{V}$ & & & \\
\hline 6. Establish a government gas infrastructure development intervention fund & $\boldsymbol{V}$ & & & \\
\hline 7. Establish a coordinating agency to drive CNG use & $\boldsymbol{V}$ & $\boldsymbol{V}$ & $\boldsymbol{V}$ & $\boldsymbol{V}$ \\
\hline 8. Separate regulatory and operational functions of NNPC & & & & $\boldsymbol{V}$ \\
\hline 9. Expand alternative fuel options to include LPG & & & $\boldsymbol{v}$ & \\
\hline \multicolumn{5}{|l|}{ 10. Remodel and upgrade delivery facilities at the sea ports } \\
\hline 11. Extend gas transmission lines nationwide & & & $\boldsymbol{V}$ & \\
\hline \multicolumn{5}{|l|}{ Transportation sector reform } \\
\hline 12. Develop a comprehensive transportation policy & & & $\boldsymbol{V}$ & \\
\hline 13. Develop vehicle emissions standards & & $\boldsymbol{V}$ & $\boldsymbol{V}$ & $\bar{v}$ \\
\hline 14. Develop a NGV safety assurance plan & & $\checkmark$ & $\boldsymbol{V}$ & $\boldsymbol{\nu}$ \\
\hline 15. Government and industry to establish retrofitting workshops & & & & $\checkmark$ \\
\hline 16. Offer incentives for auto mechanics on retrofitting training & & & & $\checkmark$ \\
\hline 17. Introduce retrofitting courses in federal technical colleges & & & & $\bar{v}$ \\
\hline \multicolumn{5}{|l|}{ Fiscal and operational incentives } \\
\hline 18. Offer tax rebate on land used for CNG stations & & & $\boldsymbol{V}$ & \\
\hline 19. Import duty concession for retrofitting kits, CNG equipment and components & & & $\boldsymbol{\nu}$ & \\
\hline \multicolumn{5}{|l|}{ 20. Offer incentives to vehicle owners to convert to NGV } \\
\hline 21. Offer 50-75\% subsidy on LPG conversion kits & & & $\boldsymbol{V}$ & \\
\hline 22. Offer incentive to mass-transit companies to use NGV & & $\checkmark$ & & $\checkmark$ \\
\hline \multicolumn{5}{|l|}{ Public awareness } \\
\hline 23. Undertake public awareness campaign & & & $\boldsymbol{V}$ & $\checkmark$ \\
\hline 24. Mandate government at all levels to include NGV in their fleet & $\boldsymbol{V}$ & & $\boldsymbol{V}$ & \\
\hline 25. NNPC to site CNG stations in strategic locations & $\boldsymbol{V}$ & & & \\
\hline 26. Involve senior government officials in the promotion of NG & $\boldsymbol{V}$ & & & \\
\hline
\end{tabular}




\section{Conclusion and Policy Implications}

This study investigated the barriers to the use of CNG as an automotive fuel in Nigeria and how these can be overcome. Whereas the main driver of natural gas initiatives in Nigeria is consistent with the quest for economic benefits/considerations, environmental concern/benefits and energy security as seen in many countries, the analysis showed a wide gap in the implementation approach when compared to the critical success factors for the adoption of CNG as an automotive fuel. While the study identified 31 barriers, only five were common to all the stakeholder groups, and three gained the support of 3 stakeholder groups. These are the absence of specific regulation and standards for natural gas vehicles; poor and sparse gas transmission and distribution infrastructure; the general inexperience of the population with gas handling; the safety of the converted vehicles; and the absence of public awareness programmes to promote the automotive use of natural gas.

From the consistent submissions of participants, the study concludes that following might gain acceptance among stakeholders:

i. Energy market reforms: Gradual and well-signposted removal of subsidies on the pump price of gasoline and kerosene, adoption of a market-based pricing for domestic supply of NG and the establishment of an agency to coordinate implementation, build consensus on appropriate incentives, facilitate retrofitting workshops and collaborate with other regulators;

ii. Transportation sector reform: Development of vehicle emissions standards and an NGV safety assurance plan

iii. Fiscal and operational incentives: Introduction of incentives to mass-transit companies to use NGV

iv. Public awareness: campaign on the benefits of CNG as an automotive fuel to generating demand - especially in Benin, where there are refuelling stations and the mandatory inclusion of NGV in government fleet at all levels 
Although the proposal for the use of LPG as automotive fuel was not a widespread view, it is worth considering, as LPG is cheaper and faster to deploy than CNG and the existing technical limitations to the domestic supply of LPG may benefit from increased consumption. Given existing LNG capabilities, the country may also exploit LNG for the heavy-duty vehicle segment. Similarly, cherry picking the separation of the dual role of NNPC, a possible high-impact, less controversial provision of the PIB and similar clauses for passage while dialogue continues with concerned stakeholders on other issues may provide an impetus for investment and growth. We suggest that Nigeria borrows a lead from Argentina where government sited refuelling stations strategically to boost the safety credentials of CNG and ultimately market confidence. We, therefore, recommend the involvement of the NNPC through strategic siting of CNG refuelling stations under its mega station scheme.

This study has developed a deeper understanding of barriers and possible policy interventions relating to the use of CNG as an automotive fuel, and these will be useful in building consensus amongst stakeholders in charting pathways for successful adoption. Further work will employ the Delphi survey technique to explore the potential for consensus amongst study participants on both the identified likely barriers and the possible policy interventions.

\section{REFERENCES}

Bala-Gbogbo, E., Ibukun, Y. 2013. Nigeria Risks \$185 Billion Loss From New Law, Oil Companies. Bloomberg [Online]. Available at: http://www.bloomberg.com/news/articles/2013-08-22/nigeria-risks185-billion-loss-from-new-law-oil-companies-say

Bowman, A., 2012, Challenges ahead for Nigeria's oil and gas industry. . Financial Times, [Online] July 24. Available at: <<http://blogs.ft.com/beyond-brics/2012/07/24/challenges-ahead-for-nigerias-oil-andgas-industry/ $>>$ [Accessed 11 August 2014]

Bryson, J. ,2004. What to do when stakeholders matter. Public Management Review, 6 (1), p.21 - 23.

Buzcu-Guven, B., Harriss, R., and Hertzmark, D., 2010.Gas flaring and venting: extent, impacts and remedies. [pdf] Available from: <http://bakerinstitute.org/files/439/> [Accessed 10 February 2014].

Byrne, M.R. And Polonsky, M.J., 2001. Impediments to consumer adoption of sustainable transportation: alternative fuel vehicles. International Journal of Operations \& Production Management, 21(12), pp. 1521-1538.

Chang, H. and Chen, P., 2009. Exploring senior officials’ policy beliefs regarding sustainable transportation. Transportation Research Part D: Transport and Environment, 14(4), pp. 249-254 ISSN 1361-9209.

Chilton, K.W., 2000. Reengineering US environmental protection. Business Horizons, 43(2), pp. 7-16. 
Clift, R. and Wright, L., 2000. Relationship between environmental impacts and added value along the supply chain. Technological Fore-Casting and Social Change, 65, pp. 281-295.

Cohen D, Crabtree B., 2006. Qualitative Research Guidelines Project. [Online] Available at: http://www.qualres.org/HomeHomo-3804.html [Accessed 25 February 2015]

Collantes, G. and Melaina, M.W., 2011. The co-evolution of alternative fuel infrastructure and vehicles: a study of the experience of Argentina with compressed natural gas. Energy Policy, 39, (2), pp. 664-675 ISSN 0301-4215.

Eden, C. and Ackermann, F.,1998. Making Strategy: The Journey of Strategic Management, p117, London: Sage Publications.

Energy Information Administration (EIA), 2013. Country Analysis: Nigeria. [Pdf]. U.S.. Last Updated December 30, 2013. Available at: http://www.eia.gov/countries/analysisbriefs/Nigeria/nigeria.pdf [Accessed 18 August 2014]

Energy Safety, 2012. What is LPG and natural gas? [Online] Available at: http://www.med.govt.nz/energysafety/consumer/safe-living-with-gas-lpg/what-is-lpg-and-natural-gas [Accessed 6 January 2013]

Fletcher, A. et al., 2003. Mapping stakeholder perceptions for a third sector organization. Journal of Intellectual Capital 4(4), 505-527.

Freeman, R. E., 1984. Strategic management: A stakeholder approach. Boston: Pitman

Friedman, T., 2000. The Laus and the Olive Tree: Understanding Globalization, New York: Anchor.

Gladwell, M., 2000. The Tipping Point: How Little Things Can Make a Big Difference Boston. MA: Little Brown and Company.

Huntington, S., 1996. The Clash of Civilizations and the Remaking of World Order, New York: Simon \& Schuster.

Igweonu, E.I. and Mbabuike I.U., 2011.Utilization of compressed natural gas in Nigeria; A case for natural gas vehicles. Continental J. Renewable Energy 2 (2): 1 - 9, 2011 ISSN: 2251 - 0494

IPCC TAR WG1 (2001), Houghton, J.T.; Ding, Y.; Griggs, D.J.; Noguer, M.; van der Linden, P.J.; Dai, X.; Maskell, K.; and Johnson, C.A., ed., Climate Change 2001: The Scientific Basis, Contribution of Working Group I to the Third Assessment Report of the Intergovernmental Panel on Climate Change, Cambridge University Press, ISBN $\underline{0-521-80767-0}$ (pb: $\underline{0-521-01495-6}$ ).sz

Kajornboon, A. B. (2005). Using interviews as research instruments. The e-Journal for Researching Teachers, 2(1). Available at http://www.culi.chula.ac.th/e-

Journal/bod/Annabel.pdf [Accessed 11 August 2013]

Merriam, S., 1998. Qualitative Research and Case Study Applications in Education. San Francisco: Jossey-Bass.

National Automotive Council of Nigeria (NAC), 2013. Nigeria Automotive Industry. Available at: www.nac.org.ng(accessed 18.08.14)

Natural Gas Vehicles (NGV) Global, 2005. Key drivers for natural gas powered buses in China. [online] [viewed 20 January 2013] Available at: http://www.ngvglobal.com/key-drivers-for-natural-gas-poweredbuses-in-china-1207

National Automotive Council of Nigeria (NAC), 2013. Official website. [viewed 18 August 2014] Available at: http://www.nac.org.ng

Nijboer, M., 2010. The contribution of natural gas vehicles to sustainable transport. [pdf] Paris: International Energy Agency. Available from: 
$<$ http://www.iea.org/publications/freepublications/publication/natural_gas_vehicles.pdf> [Accessed 27 October 2012].

Nigerian National Petroleum Corporation (NNPC),, 2014 .Joint Venture operations [Online]. Available at $<$ http://www.nnpcgroup.com/nnpcbusiness/upstreamventures.aspx > [Accessed 10 August 2014]

Nwaoha, C. and Iyoke, U.J., 2013. Review on Natural Gas Utilization and Cutting Carbon Emissions: How viable is Compressed Natural Gas for Road Vehicle Fuel? Journal of Energy Technologies and Policy, 3(5), pp. 37-46 ISSN2224-3232

Ogunlowo O.O., Bristow A.L. and Sohail M., 2016. Understanding the barriers to the use of compressed natural gas as an automotive fuel in Nigeria: lessons from international markets. NGV Transportation Magazine.

Ogunlowo O.O., Bristow A.L. and Sohail M.,2015. Developing Compressed Natural Gas as an automotive fuel in Nigeria: lessons from international markets, Energy Policy 76, January 2015, 7-17. http://dx.doi.org/10.1016/j.enpol.2014.10.025

Ogunlowo, O.O., Bristow, A.L. and Sohail, M., 2013. Exploration of Compressed Natural Gas for road transportation in Nigeria: lessons from high growth natural gas vehicle markets. In: The British University in Dubai, SB13 Dubai - Advancing the Green Agenda; Technology, Practices and Policies. Dubai, 8-10 December 2013.

Ogunmade, O., Ejiofor, A., 2014. Oil Price Decline Opens Window for Subsidy Removal, Increased Savings.ThisdayLive. Available at: < http://www.thisdaylive.com/articles/oil-price-decline-openswindow-for-subsidy-removal-increased-savings/191510/> . (accessed 17.10.14)

Okafor, C. 2013. Petroleum Industry Bill: In Whose Interest? Thisday Live. Available at:

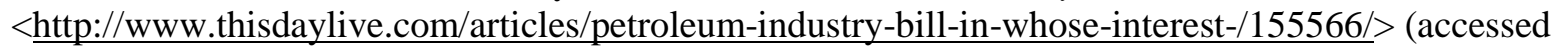
$06.0813)$.

Omotola, J. S., 2006. The Next Gulf? Oil Politics, Environmental Apocalypse and Rising Tension in the Niger Delta, ACCORD Occasional Paper Series 1 (3): 3-31.

Patterson, M.E. and Williams, D.R., 2002. Collecting and analyzing qualitative data: hermeneutic principles, methods and case examples. Champaign, Illinois: Sagamore Publishing.

PERC, 2014.Case Studies and Fact Sheets. [Online]. Propane Education \& Research Council.Available at $<<$ http://www.propane.com/on-road-fleets/case-studies-and-fact-sheets/>> [Accessed 18 August 2014].

Pike Research, 2012. Light duty natural gas vehicles. [pdf] [viewed 30 January 2013] Available at: http://www.pikeresearch.com/wordpress/wp-content/uploads/2012/07/LDNGV-12-ExecutiveSummary.pdf

Project Management Institute (PMI), 2008. A guide to the project management body of knowledge (PMBOK) (3rd ed.). Project Management Institute. Newtown Square, Pennsylvania USA.

Raslavicius, L., ArturasKersys, A., Mockus, S., Kersiene, N and Starevicius, M , 2014. Liquefied petroleum gas (LPG) as a medium-term option in the transition to sustainable fuels and transport. Renewable and Sustainable Energy Reviews, 32, pp. 513-525

Shields, P. and Hassan, T., 2006. Intermediate theory: the missing link in successful student scholarship. Journal of Public Affairs Education, 12(3), pp. 313-334.

Sumaila, A., 2013.Building Sustainable Policy Framework for Transport Development: A Review of National Transport Policy Initiatives in Nigeria.Journal of Sustainable Development Studies, 2(1), pp.123

Willis, J.W., 2007. Foundations of qualitative research: interpretive and critical approaches. London: SAGE. 
World Bank. 1996. Nigeria - Federal public expenditure review. World Development Sources, WDS 1996. Washington, DC: World Bank. Available at:

$<$ http://documents.worldbank.org/curated/en/1996/03/696677/nigeria-federal-public-expenditure-review $>$ (accessed 11.01.14)

Yeh, S., 2007. An empirical analysis on the adoption of alternative fuel vehicles: the case of natural gas vehicles. Energy Policy, 35(11), pp. 5865-5875 ISSN 0301-4215.

Yosie, T.F., and Herbst, T.D., 1998. Managing and communicating stakeholder-based decision making. Human and Ecological Risk Assessment: An International Journal, 4(3), 643-646, ISSN 1080-7039. 